\title{
Peningkatan Penguasaan Tata Bahasa Prancis Mahasiswa melalui Model Inkuiri
}

\author{
Nani Kusrini*, Diana Rosita \\ FKIP Universitas Lampung J1. Prof. Dr. Sumantri Brojonegoro No.1 Bandar Lampung \\ *Correspondinge-mail : nani.kusrini7@gmail.com
}

Received: 27 September 2017 Accepted: 1 November $2017 \quad$ Published: November 2017

\begin{abstract}
Improving French Grammar Mastery through Inquiry Model on the $3^{\text {rd }}$ Semester Students of French Departement of Unila. This research aimed to improve student's mastery of french grammar through inquiry model. The method used in this research was qualitative by conducting an action research. This action research which consisted of 2 cycles involved 34 students in the $3^{\text {rd }}$ semester of French Department, University of Lampung. The data which were in the form of test and observation results were analyzed descriptively. The results of this research showed that inquiry model which is a learning model that emphasizes discovery learning can improve the achievement of French students in mastering and understanding French grammar, as well as minimizing gaps in achievement generated through group work (cooperative).
\end{abstract}

Keywords: language teaching, French grammar, inquiry model, discovery learning

\begin{abstract}
Abstrak: Peningkatan Penguasaan Tata Bahasa Prancis melalui Model Inkuiri pada Mahasiswa Semester 3 Prodi Bahasa Prancis Universitas Lampung. Tujuan penelitian ini adalah untuk meningkatkan penguasaan dan pemahaman mahasiswa terhadap tata bahasa Prancis melalui model inkuiri. Penelitian ini menggunakan metode kualitatif yaitu penelitian kaji tindak. Penelitian kaji tindak dengan dua siklus ini melibatkan 34 mahasiswa semester 3 pendidikan bahasa Prancis Universitas Lampung. Data berupa hasil tes dan hasil observasi dianalisis secara deskriptif. Hasil penelitian ini menunjukkan bahwa model inkuiri yang merupakan model pembelajaran yang menekankan pada penemuan (discovery learning) dapat meningkatkan prestasi mahasiswa bahasa Prancis dalam menguasai dan memahami tata bahasa Prancis, serta meninimalkan kesenjangan pada prestasi yang dihasilkan melalui kerja kelompok (kooperatif).
\end{abstract}

Kata kunci : pengajaran bahaasa, tata bahasa Prancis, model inkuiri, discovery learning

\section{PENDAHULUAN}

Tata bahasa memiliki peranan penting pada pengajaran bahasa karena merupakan pondasi untuk menunjang keempat keterampilan berbahasa. Hal ini senada dengan apa yang disampaikan oleh Vigner (2004:15) yang mengatakan bahwa tata bahasa bertujuan untuk menjelaskan kondisi-kondisi tentang penggunaan yang tepat dari suatu bahasa baik lisan maupun tulis (la grammaire a pour objectifs de préciser les conditions d'un emploi correct d'une langue). Meskipun merupakan hal mendasar yang harus dikuasai ketika mempelajari suatu 
bahasa khususnya bahasa asing, tidak sedikit siswa yang alergi mendengar kata 'tata bahasa'. Hal ini dikarenakan bayangan tentang pelajaran yang berisi begitu banyak aturan dengan beberapa pengecualian yang harus dihafalkan sudah menghantui pikiran siswa. Ditambah lagi dengan banyaknya latihan yang harus dikerjakan tanpa mengetahui dengan pasti mau diapkan atau apa tujuan dari semua hal itu membuat siswa menjadi apriori terhadap tata bahasa.

Hal yang sama juga terjadi pada mahasiswa semester 3 prodi pendidikan bahasa Prancis. Nilai akhir mahasiswa tahun akademik 2015/ 2016 yang berjumlah 39 orang pada mata kuliah Grammaire Pré-Élémentaire di semester pertama menunjukkan perbedaan yang signfikan, seolaholah mahasiswa di angkatan tersebut terbagi menjadi dua kubu yaitu kelompok yang bisa sekali dengan jumlah 12 orang (mendapat A) dan kelompok yang tidak bisa sama sekali dengan jumlah 17 orang (mendapat nilai d" C). Banyaknya mahasiswa yang mendapat nilai d" C dan perbedaan yang sangat menyolok antara jumlah mahasiswa yang mendapatkan nilai Adan d' C ini menggugah peneliti untuk mencari tahu alasan atau hal yang menyebabkan perbedaan penguasaan ini.

Metode inkuiri merupakan metode yang memungkinkan siswa berperan aktif untuk mencaritahu tentang sesuatu sendiri. Layaknya seperti teka-teki, siswa merasa tergugah dan tertantang untuk mengetahui jawaban dari tekateki tersebut. Seperti yang disimpulkan oleh Sumantri (1998:164) bahwa metode inkuiri atau metode penemuan adalah cara penyajian pelajaran yang memberi kesempatan kepada peserta didik untukmenemukan informasi dengan atau tanpa bantuan guru. Metode penemuan melibatkan peserta didik dalam proses-proses mental dalam rangka penemuan memungkinkan para peserta didik menemukan sendiri informasiinformasi yang diperlukan untuk mencapai tujuan belajarnya.
Metode ini dapat diterapkan pada pengajaran tata bahasa karena dengan metode ini mahasiswa dapat berperan aktif karena tidak hanya disodori sejumlah aturan tetapi merekalah yang akan menemukan aturan tersebut dan menyimpulkannya. Tagliante (1994:151) menyatakan bahwa jika siswa menemukan sendiri aturan-aturan bahasa, mereka akan memahami dan mengingatnya lebih mudah (Si des apprenants trouvent eux-mîmes les règles de la langue, ils les comprendront et se les rappelleront d'une façon facile). Atas dasar uraian tersebut, maka peneliti bermaksud menerapkan model inkuiri pada pengajaran tata bahasa (grammaire) untuk meningkatkan penguasaan dan pemahaman mahasiswa terhadap tata bahasa sebagai penunjang penguasaan bahasa Prancis.

\section{METODE}

Seperti telah disebutkan sebelumnya bahwa tujuan penelitian ini adalah untuk mengetahui pengaruh model inkuiri pada peningkatan kemampuan tata bahasa Prancis pada mahasiswa prodi pendidikan bahasa Prancis, maka metode penelitian yang digunakan dalam penelitian ini adalah metode kualitatif. Menurut Denzin dan Lincoln (2009) dalam Noor (2011 : 33), kata kualitatif menyiratkan penekanan pada proses dan makna yang tidak dikaji secara ketat atau belum diukur dari sisi kuantitas, jumlah, intensitas, atau frekuensinya. Tata bahasa yang merupakan kemampuan dasar untuk menunjang pembelajar menguasai keempat kompetensi berbahasa yang lain masih menjadi hal yang relatif sulit dikuasai oleh mahasiswa bahasa Prancis semester III dan hal ini terefleksi dalam tulisan atau ucapan mereka dalam bentuk kesalahan gramatikal yang kadangkala menghasilkan kalimat/ujaran yang tidak bermakna atau makna yang berbeda dari yang ingin disampaikan. Sebagai pengajar yang mengampu mata kuliah ini, penulis merasa perlu 
untuk mengadakan penelitian untuk mencari solusi atau alternatif cara pengajaran yang berbeda untuk membantu memecahkan masalah ini.

Atas dasar permasalahan tersebut, metode yang tepat untuk penelitian ini adalah penelitian kaji tindak. Penelitian kaji tindak sebetulnya penelitian yang cukup lazim dipakai oleh penelitipeneliti ilmu sosial dalam rangka menggali temuantemuan berdasarkan pengalaman sehari-hari, berorientasi kepada pengalaman sehari-hari sering mempunyai keunikan yang kasusistik. Dalam dunia pengajaran ada beberapa istilah yang terkait dengan penelitian kaji tindak, yaitu belajar melalui pengalaman (experimential learning), kaji ulang (reflective teaching), dan kaji tindak (action research), yang lebih kita kenal dengan istilah kaji tindak kelas (Setiyadi, 2006: 69-270).

Hal yang sama juga diungkapkan oleh Musa (1988 : 11) yang menyatakan bahwa penelitian tindakan adalah penelitian yang bertujuan untuk mengembangkan keterampilan baru atau cara pendekatan baru untuk memecahkan masalah dengan penerapan langsung di dunia kerja atau dunia aktual yang lain.

Walaupun tergolong ke dalam penelitian kualitatif, penelitian kaji tindak mempunyai karakteristik yang cukup menyolok. Karakteristik penelitiann kaji tindak yang utama adalah bersiklus, berkolaborasi, dan ber efleksi. Ketiga karakteristik itulah yang membedakan penelitian kaji tindak dengan penelitian kualitatif lainnya.

\section{Bersiklus}

Dalam sebuah penelitian kaji tindak terdapat beberapa siklus yang selalu terkait satu sama lain. Satu siklus dalam penelitian tipe ini terdiri dari tindakan dan refleksi (Dick, 2000) dalam Setiyadi (2006 : 271). Hasil refleksi pada siklus yang pertama akan menjadi bahan perencanaan dalam siklus yang kedua dan seterusnya hingga terbentuk beberapa siklus yang saling terkait dalam satu penelitian kaji tindak.

\section{Berkolaborasi}

Penelitian ini harus melibatkan pihak lain karena penelitian ini termasuk ke dalam pendekatan kualitatif. Keterlibatan pihak lain diartikan sebagai partnership yang mempunyai peran yang relatif sama antara yang satu dan lainnya. Perbedaan dalam tugas penelitian hanya terkait pada pembagian kerja secara praktis, namun semua anggota tim mempunyai wewenang yang relatif sama dalam merencanakan, melaksanakan dan memaknai hasil temuannya.

\section{Refleksi}

Refleksi adalah bagian terpenting dalam siklus pengajaran. Millet, dkk (2001) dalam (Setiyadi, 2006: 274) menawarkan empat langkah penting untuk berefleksi, yaitu mengalami, mendeskripsikan, menganalisis, dan merencanakan langkah berikutnya.

\section{Waktu dan tempat penelitian}

Penelitian ini dilakukan dengan mengambil jam mata kuliah Grammaire Pré-Intermédiaire yang diselenggarakan pada semester ganjil tahun akademik 2016/2017 di kelas gedung K FKIP Universitas Lampung setiap hari Kamis pukul 07:30 - 9:30 selama beberapa minggu.

\section{Populasi dan sampel}

Populasi adalah wilayah generalisasi yang terdiri atas: obyek dan subyek yang memiliki kualitas dan karakteristik tertentu yang diterapkan oleh peneliti untuk dipelajari dan kemudian ditarik kesimpulannya (Sugiyono, 2006 : 117). Populasi dalam penelitian ini adalah semua mahasiswa bahasa Prancis semester III yang mengambil mata kuliah Grammaire Pré-Intermédiaire.

Menurut Suharsimi apabila subjek kurang dari 100 lebih baik diambil semua sebagai penelitian populasi atau penelitian sensus (Firdaus, 2012:33). Jumlah mahasiswa semester III yang mengambil mata kuliah Grammaire Pré- 
Intermédiaire berjumlah 34 orang. Oleh karena itu, semua mahasiswa tersebut menjadi sampel dalam penelitian ini.

\section{Prosedur}

Seperti pendapat Kemmis dan McTaggart (1982) dalam Setiyadi (2006: 277), secara umum kaji tindak dapat disusun dalam beberapa tahapan, yaitu mengidentifikasi permasalahan, memikirkan langkah-langkah perbaikan, dan melaksanakan serta memonitor kegiatan perbaikan.

\section{Mengidentifikasi permasalahan}

Pada latar belakang masalah telah dijelaskan bahwa prestasi mahasiswa bahasa Prancis semester III pada mata kuliah tata bahasa seolah-olah terbagi menjadi dua yaitu sekelompok mahasiswa sangat menguasai sedangkan kelompok yang lain sangat tidak menguasai. Permasalahan yang timbul adalah mengapa prestasi mahasiswa untuk mata kuliah ini sangat jauh berbeda.

\section{Memikirkan langkah - langkah perbaikan}

Setelah menentukan permasalahan tersebut di atas dan setelah mengkaji teori/ referensi mengenai model inkuiri, maka peneliti memutuskan untuk mencobakan model inkuiri untuk mengatasi kesenjangan pada hasil prestasi mahasiswa di mata kuliah tata bahasa ini. Seperti telah dijelaskan pada landasan teori, model inkuiri adalah model pengajaran yang menuntut keaktifan siswa dan menempatkan siswa sebagai subjek dalam proses belajar di dalam kelas. Dalam kaitannya dengan mata kuliah tata bahasa, mahasiswa diarahkan agar mampu menemukan sendiri rumus/pola suatu bahasan mengenai tata bahasa Prancis sehingga diharapkan dengan menemukannya sendiri, mahasiswa dapat lebih memahami.

\section{Mencobakan dan memonitor kegiatan perbaikan}

Pada tahap ini, peneliti mencobakan model inkuiri untuk mengajarkan bahasan mata kuliah Grammaire Pré-Intermédiaire mengenai 'la comparaison' (perbandingan). Tema tentang la comparaison sendiri terdiri dari beberapa sub bahasan yaitu ' $l e$ comparatif'(mencakup adjectif, nom, adverbe dan verbe) dan juga 'le superlatif' yang mencakup hal yang sama. Pada tahap ini diterapkanlah fase-fase pada model pengajaran berbasis inkuiri yang dimulai dengan:

\section{Penyajian Masalah}

Peneliti menjelaskan sekilas tentang konsep inkuiri serta tahapan yang ada dalam model ini dan hal-hal yang harus dilakukan mahasiswa. Kemudian sebagai stimulus, dosen memberikan video mengenai konsep tentang perbandingan dan syaratsyarat apa saja yang wajib hadir di dalamnya. Tahap untuk siklus pertama ini diakhiri dengan pertanyaan bagaimana membentuk kalimat menggunakan bentuk le comparatif dalam bahasa Prancis.

2. Pengumpulan dan Verifikasi Data Mahasiswa yang sudah dikelompokkan ke dalam kelompok-kelompok kecil mulai membaca dan menganalisis bacaanbacaan singkat yang di dalamnya mengandung bentuk le comparatif.

3. Mengadakan eksperimen dan pengumpulan data

Bentuk-bentuk yang dianggap le comparatif dikeluarkan dari bacaan dan kemudian dikelompokkan berdasarkan kesamaan bentuk. Dari data-data kalimat tersebut, mahasiswa mulai membuat hipotesis tentang rumus/pola pembentukan bentuk le comparatif dan kemudian menteskan hasil hipotesisnya. 
4. Merumuskan penjelasan

Setelah menganalisis dan mentes hipotesisnya, mahasiswa diminta menyusun kaidah/rumus untuk membentuk pola kalimat le comparatif dalam bahasa Prancis.

5. Mempresentasikan hasil temuannya. Masing-masing kelompok menjelaskan hasil temuan dan hasil diskusi kelompoknya.

6. Peran peneliti/dosen Penelitimengevaluasi hasil temuan/rumusan mahasiswa dengan menambahkan keterangan dan memberikan contoh yang lebih untuk memantapkan pemahaman mahasiswa.

7. Mengerjakan tes

Pada akhir sesi, mahasiswa diberikan tes mengenai le comparatif untuk dikerjakan secara individual. Hasil tes ini kemudian juga dijadikan bahan evaluasi peneliti selain lembar observasi yang dilakukan oleh rekan peneliti.

8. Peran observer Observer berperan mengamati jalannya proses dan mencatat semua hal seperti tingkah laku mahasiswa dan juga penjelasan/arahan dosen ketika proses inkuiri berlangsung.

\section{Data, Instrumen dan Teknik Pengumpulan Data}

Data yang digunakan dalam penelitian ini adalah hasil tes mahasiswa yang diberikan tiap siklus sebagai data primer dan juga lembar observasi sebagai data sekunder.

\section{Teknik Analisis Data}

Adapun teknik yang digunakan untuk menganalisis data adalah :

1. Mengevaluasi hasil tes

Data yang diperoleh dari lembar kerja mahasiswa dipresentasikan dengan rumus :

$$
\mathrm{X}=\frac{\text { Jumlah jawaban benar }}{\text { skor }}
$$

2. Indikator dan Tolak Ukur

Berikutnya, terkait standar penilaian digunakan sistem Penilaian Acuan Patokan (PAP) yang ada pada buku panduan FKIP Unila tahun 2015. Hasil evaluasi dikategorikan sebagai berikut:

Tabel 1. Penilaian Acuan Patokan

\begin{tabular}{ccc}
\hline $\begin{array}{c}\text { Angka Mutu } \\
\text { (skala 0 - 10) }\end{array}$ & $\begin{array}{c}\text { Angka Mutu } \\
\text { (skala 0 -4) }\end{array}$ & $\begin{array}{c}\text { HM (skala } \\
\text { kulitatif) }\end{array}$ \\
\hline $80-100$ & 4 & $\mathrm{~A}$ \\
$65-79$ & 3 & $\mathrm{~B}$ \\
$56-64$ & 2 & $\mathrm{C}$ \\
$45-54$ & 1 & $\mathrm{D}$ \\
$0-44$ & 0 & $\mathrm{E}$ \\
\hline
\end{tabular}

\section{HASIL DAN PEMBAHASAN}

Mata kuliah tata bahasa (grammaire) adalah mata kuliah kebahasaprancisan yang diajarkan pada mahasiswa secara berjenjang dari semester 1 sampai dengan semester 6 . Mata kuliah Grammaire Pré-Intermédiaire diajarkan pada mahasiswa semester 3 dan merupakan kelanjutan dari Grammaire Élémentaire pada semester 2. Seperti telah dibahas pada landasan teori, beberapa ahli bahasa mengutarakan pendapat yang berbeda mengenai posisi pengajaran tata bahasa pada pembelajaran bahasa kedua. Sekelompok ahli menyatakan bahwa peran tata bahasa tidaklah terlalu penting bagi pembelajar bahasa asing untuk menguasai kompetensi berbahasa yang dipelajarinya. Di sisi lain, kelompok yang lain menyatakan peran tata bahasa sangat penting karena memberikan pengetahuan tentang membentuk satuan-satuan linguistik yang 
penting untuk menunjang pencapaian kompetensi berbahasa yang lain.

Dalam prakteknya, susah untuk menguasai kompetensi berbahasa; membaca, menyimak, atau bukan jaminan untuk dapat keempat kompetensi berbahasa tersebut dengan baik. Pengajaran tata bahasa seyogyanya disesuaikan dengan fungsinya untuk menunjang pencapaian hal tersebut.

Bahasa Prancis berbeda dengan bahasa Inggris dan jauh berbeda lagi dengan bahasa Indonesia. Selain memiliki atauran kala/waktu (tense) yang banyak jumlahnya, bahasa Prancis termasuk kelompok bahasa yang membedakan ajektiva dan nominanya dalam dua jenis (genre), laki-laki (masculin) dan perempuan (féminin) seperti bahasa Arab, Portugis, Italia $\mathrm{dsb}$. Secara garis besar, perbedaan yang terdapat antara bahasa Prancis dan bahasabahasa yang terlebih dahulu dikuasai dan dikenal oleh mayoritas mahasiswa bahasa Prancis semester 3 ini, yaitu bahasa Indonesia dan bahasa Inggris, menimbulkan kesulitan untuk menguasai tata bahasa Prancis. Hal tersebut terefleksikan pada prestasi mahasiswa-mahasiswa ini pada semester sebelumnya pada mata kuliah tata bahasa.

Untuk memecahkan permasalahan tersebut, peneliti mencobakan model inkuiri untuk pembelajaran tata bahasa pada mata kuliah Grammaire Pré-Intermédiaire, atas dasar teori bahwa selain melatih mahasiswa untuk berperan aktif dalam proses belajar. Mahasiswa bukanlah obyek tetapi subyek dalam kelas dengan belajar menemukan dan menganalisis sesuatu, dalam hal ini menemukan pola tata bahasa tertentu. Selain membuat mereka menjadi aktif, metode ini dapat membuat mahasiswa dapat mengingat lebih baik yang ditemukannya, seperti yang diungkapkan oleh Tagliante (1994:151) bahwa jika siswa menemukan sendiri aturan-aturan bahasa, mereka akan memahami dan mengingatnya lebih mudah (Si des apprenants trouent eux-mîmes les règles de la langue, ils les comprendront et se les rappelleront d'une façon facile).

\section{Siklus I}

Sesuai dengan silabus yang telah disusun dan dipersiapkan untuk mata kuliah ini. Topik bahasan untuk tiga pertemuan di awal semester adalah la comparaison (perbandingan). Sub pokok bahasannya adalah le comparatif dan le superlatif. Penelitian kaji tindak mempunyai ciri bersiklus yang masing-masing siklus terdiri dari tindakan dan refleksi. Refleksi sendiri terdiri dari empat langkah yaitu mengalami, mendeskripsikan, menganalisis, dan merencanakan langkah berikutnya.

Hal-hal lain yang perlu diperhatikan dalam pelaksanaan model inkuiri siklus pertama ini yaitu pada awal pelaksanaan beberapa mahasiswa masih merasa bingung tentang apa yang harus dilakukan karena mereka belum pernah mengenal dan mencoba model pembelajaran ini. Belum semua mahasiswa terlibat aktif. Sebagian mahasiswa/kelompok juga masih terlihat pasif dan nampak belum dapat bekerja sama dengan anggota kelompok yang lain.

Kebingungan mahasiswa ini dikarenakaan mereka belum terbiasa dengan model pengajaran yang lain, khususnya model inkuiri. Model belajar tradisional yang biasa diterapkan dalam pengajaran tata bahasa yaitu dengan penjelasan rumus/pola pembentukan kalimat dari dosen kemudian dilanjutkan dengan mengerjakan soal-soal dan kemudian membahasanya bersama-sama di kelas, masih melekat pada diri mahasiswa. Kegiatan pembelajaran pada siklus I dapat dilihat pada Tabel 2. 
Tabel 2. Fase-fase inkuiri pada tahap tindakan siklus I

\begin{tabular}{cc}
\hline Dosen & Mahasiswa \\
\hline A. Pada tahap inilah model inkuiri diterapkan. &
\end{tabular}

\section{Penyampaian masalah}

- Membagi mahasiswa ke dalam beberapa kelompok masing-masing terdiri dari 3/4 orang.

- Menyampaikan permasalahan dengan menggunakan video tentang konsep perbandingan

- Menjelaskan tentang prosedur inkuiri.

\section{Pengumpulan dan verifikasi data}

- Membagikan beberapa wacana singkat dan meminta mahasiswa untuk menemukan bentuk yang bermakna perbandingan.

- Dosen memfasilitasi pemahaman mahasiswa dengan menjawab ya atau tidak untuk pertanyaan mahasiswa.

3. Mengadakan eksperimen dan mengumpulkan data

- Meminta mahasiswa mengumpulkan kalimat-kalimat yang bermakna perbandingan yang didapat dari wacanawacana singkat tersebut.

- Meminta mahasiswa secara bergantian menerjemahkan kalimat yang ditemukan.

\section{Menyusun hipotesis}

- Meminta mahasiswa untuk mengumpulkan kalimatkalimat yang mempunyai pola yang sama.

- Meminta mahasiswa merumuskan pola kalimat-kalimat yang mempunyai keteraturan yang sama.

\section{Presentasi hasil}

- Meminta masing-masing kelompok mempresentasikan hipotesisnya.

- Mengumpulkan kelompok yang mempunyai hasil rumusan yang sama dan menguji hasil rumusan dengan memberikan contoh yang lain.

- Menyimpulkan rumusan yang tepat (le comparatif) dari hasil diskusi mahasiswa dan menguatkan pemahaman dengan memberikan contoh soal yang lain.
- Mahasiswa menyimak video untuk mengingat kembali tentang konsep perbandingan.

- Mahasiswa dalam kelompoknya menyimak tentang tahapan-tahapan pada model inkuiri.

- Mahasiswa membaca wacana dan kalimat singkat tersebut dan berusaha menganalisis bentuk perbandingan yang ada di dalamnya.

- Beberapa mahasiswa mulai mengajukan pertanyaan kepada dosen apakah bentuk yang ditemukannya termasuk bentuk perbandingan.

- Mengumpulkan dengan menuliskan kembali kalimat yang diduga bermakna perbandingan ke dalam lembar lain.

- Mahasiswa mencoba memahami arti pola kalimat yang ditemukannya.

- Mengumpulkan kalimat-kalimat temuan yang mempunyai pola/bentuk yang sama ke dalam masing-masing kelompok.

- Menganalisis bentuk tersebut dan berusaha menyusun hipotesis untuk merumuskan pola kalimat yang ditemukannya.

- Perwakilan masing-masing kelompok mempresentasi kan/mengutara kan hasil temuannya.

- Mentes rumusan hasilnya untuk contoh kata-kata yang lain.

B. Memberikan tes mengenai le comparatif

Setelah tahap tindakan selesai dilakukan, tahap berikutnya adalah deskripsi. Sebagai salah satu acuan untuk menilai proses tindakan, dievaluasilah hasil tes mahasiswa yang dilakukan pada sesi akhir percobaan yang pertama.

Tes pertama terdiri dari 15 soal isian yang dibagi menjadi tiga bagian. Banyak mahasiswa mendapatkan nilai baik untuk bagian pertama dan kedua. Sedangkan bagian ketiga yang berisi tentang menyusun kalimat dari kata-kata yang sudah diberikan, beberapa mahasiswa mendapatkan kesulitan karena ketidaktelitian antara lain tidak menuliskan konjugasi kata kerja être pad kalimat juga dalam menyesuaikan apakah subyek kalimat termasuk jenis masculin atau féminin.

Dengan mengacu Penilaian Acuan Patokan (PAP), rata-rata mahasiswa mendapatkan nilai 
B yang berada pada rentang nilai $65-79$. Sejumlah mahasiswa mendapatkan nila A ( 80 100) tetapi terdapat juga mahasiswa yang mendapatkan kategori huruf mutu D karena mendapatkan nilai antara 45-55. Rekapitulasi jumlah mahasiswa untuk kategori nilai dan persentasenya dapat dilihat dalam tabel berikut ini.

Tabel 3. Persentase Prestasi Mahasiswa pada tes I

\begin{tabular}{|c|c|c|c|c|}
\hline No. & $\begin{array}{c}\text { Angka } \\
\text { Mutu }\end{array}$ & $\begin{array}{l}\text { Huruf } \\
\text { Mutu }\end{array}$ & $\begin{array}{c}\text { Jumlah } \\
\text { Mahasiswa }\end{array}$ & $\begin{array}{c}\text { Persentase } \\
(\%)\end{array}$ \\
\hline 1. & $80-100$ & $\mathrm{~A}$ & 9 & 27,27 \\
\hline 2. & $65-79$ & B & 15 & 45,46 \\
\hline 3. & $56-64$ & $\mathrm{C}$ & 7 & 21,21 \\
\hline 4. & $45-54$ & D & 2 & 6,06 \\
\hline 5. & $0-44$ & $\mathrm{E}$ & 0 & - \\
\hline \multicolumn{3}{|c|}{ Jumlah } & 33 & 100 \\
\hline
\end{tabular}

Jika melihat hasil pada tabel di atas diketahui bahwa distribusi nilai pada tes I setelah menggunakan model inkuiri cukup merata yang mana sebagian besar hasil prestasi mahasiswa e" $\mathrm{B}$ dan jumlah nilai mahasiswa yang mendapatkan nilai d" $\mathrm{C} 27 \%$ (gabungan antara yang mendapat huruf mutu $\mathrm{C}$ dan D). Hasil ini menunjukkan bahwa model inkuiri dapat meningkatkan hasil prestasi mahasiswa khususnya pada mata kuliah tata bahasa.

Beberapa kelompok masih terlihat belum dapat bekerja sama. Sebagian anggota kelompok masih mengerjakan instruksi dosen secara individual bukan berkelompok. Hasilnya, beberapa hasil rumusan/hipotesis tentang pola pembentukan kalimat le comparatif yang dipresentasikan tidak jarang merupakan hasil kerja perorangan. Di samping itu, terdapat perbedaan antara kelompok yang sangat aktif dan kelompok yang sangat pasif. Nampaknya pemilihan anggota masing-masing kelompok secara acak harus ditinjau kembali.

Selain itu, hal yang paling signifikan pada pelaksanaan model inkuiri adalah waktu yang dibutuhkan untuk menyelesaikan satu tahapan model inkuiri ini membutuhkan waktu $\pm 2,5$ jam, lebih lama dari waktu yang dialokasikan pada awalnya yaitu 1 jam 40 menit. Waktu yang paling lama dibutuhkan pada menganalisis bentukbentuk perbandingan yang ada pada wacanawacana tersebut cukup banyak.

Berdasarkan temuan-temuan yang didapatkan dari lembar observasi, dirumuskan beberapa langkah yang harus ditempuh untuk memperbaiki proses antara lain dalam pembagian anggota kelompok. Sebelum ditentukan, sebaiknya anggota masing-masing kelompok tidak ditentukan secara random tapi cara purposive sampling sehingga tidak ada lagi kelompok yang sangat aktif dan kelompok yang sangat pasif. Untuk membangkitkan dan menghidupkan kerja sama antara anggota kelompok, diperlukanlah pembagian tugas sehingga semua anggota dapat berperan aktif.

Agar proses pengajaran menggunakan model inkuiri ini menjadi lebih singkat, pemberian contoh wacana yang akan dianalisis mahasiswa untuk menemukan bentuk perbandingan perlu diperhatikan. Perlunya disediakan contoh wacana yang lebih singkat, sehingga waktu yang diperlukan untuk satu sub bahasan kurang lebih sesuai dengan waktu yang dialokasikan untuk mata kuliah dengan bobot 2 sks, yaitu 1 jam 40 menit.

\section{Siklus II}

Pada siklus kedua terlihat adanya peningkatan dari sikap mahasiswa. Dari data observasi diketahui bahwa lebih banyak mahasiswa yang terlihat berpartisipasi aktif dalam proses pembelajaran berbasis inkuiri. Mereka lebih memahami apa yang harus dilakukan. Kerjasama antar kelompok lebih terlihat dibandingkan pada siklus pertama. Hal ini dikarenakan mereka lebih memahami langkahlangkah yang harus dilakukan. Kegiatan pembelajaran pada siklus I dapat dilihat pada Tabel 4. 
Tabel 4. Fase-fase inkuiri pada tahap tindakan siklus II

\begin{tabular}{cc}
\hline Dosen & Mahasiswa \\
\hline A. Pada tahap inilah model inkuiri diterapkan. &
\end{tabular}

\section{Penyampaian masalah}

- Membagi mahasiswa ke dalam beberapa kelompok seperti yang sudah direncanakan masing-masing terdiri dari $3 / 4$ orang.

- Mengulang secara singkat tentang materi sebelumnya (le comparatif)

- Menyampaikan permasalahan yang akan dipecahkan (le superlatif) dan menjelaskan tujuan.

- Menjelaskan tentang prosedur inkuiri.

\section{Pengumpulan dan verifikasi data}

- Membagikan beberapa kalimat/wacana singkat dan meminta mahasiswa untuk menemukan bentuk yang bermakna perbandingan le superlatif.

- Dosen memfasilitasi pemahaman mahasiswa dengan menjawab ya atau tidak untuk pertanyaan mahasiswa.

- Dosen memberikan pertanyaan-pertanyaan 'pancingan' yang mengarah untuk mencapai tujuan.

3. Mengadakan eksperimen dan mengumpulkan data

- Meminta mahasiswa mengumpulkan kalimat-kalimat yang bermakna perbandingan (le superlatif) yang didapat dari wacana-wacana singkat tersebut.

- Meminta mahasiswa secara bergantian mencoba menerjemahkan kalimat yang ditemukan.

\section{Menyusun hipotesis}

- Meminta mahasiswa untuk mengumpulkan kalimatkalimat yang mempunyai pola yang sama.

- Meminta mahasiswa merumuskan pola kalimat-kalimat yang mempunyai keteraturan yang sama.

\section{Presentasi hasil}

- Meminta masing-masing kelompok mempresentasikan hipotesisnya.

- Mengumpulkan kelompok yang mempunyai hasil rumusan yang sama dan menguji hasil rumusan dengan memberikan contoh yang lain.

- Menyimpulkan rumusan yang tepat (le superlatif) dari hasil diskusi mahasiswa dan menguatkan pemahaman dengan memberikan contoh soal yang lain.
- Mahasiswa menyimak untuk mengingat kembali tentang konsep perbandingan (le comparatif).

- Mahasiswa dalam kelompoknya menyimak tentang tahapan-tahapan pada model inkuiri serta tujuan dari model pembelajaran ini..

- Mahasiswa membaca wacana dan kalimat singkat tersebut dan berusaha menganalisis bentuk perbandingan (le superlatif) yang ada di dalamnya.

- Beberapa mahasiswa mulai mengajukan pertanyaan kepada dosen apakah bentuk yang ditemukannya termasuk bentuk perbandingan.

- Menjawab/Memahami pertanyaan 'arahan' dari dosen.

- Mengumpulkan dengan menuliskan kembali kalimat yang diduga bermakna perbandingan (le superlatif) ke dalam lembar lain.

- Mahasiswa mencoba memahami arti pola kalimat yang ditemukannya.

- Mengumpulkan kalimat-kalimat temuan yang mempunyai pola/bentuk yang sama ke dalam masing-masing kelompok.

- Menganalisis bentuk tersebut dan berusaha menyusun hipotesis untuk merumuskan pola kalimat yang ditemukannya.

- Perwakilan masing-masing kelompok mempresentasikan/mengutarakan hasil temuannya.

- Mentes rumusan hasilnya untuk contoh katakata yang lain. 
Jika melihat hasil prestasi mahasiswa pada tes kedua, diketahui adanya peningkatan. Sudah tidak ada lagi mahasiswa yang mendapatkan nilai $\mathrm{D}$, namun beberapa masih mendapatkan nilai C meskipun jumlahnya lebih sedikit daripada tes sebelumnya. Untuk lebih rinci hasil tes ini dapat dilihat pada tabel persentase di bawah ini :

Tabel 5. Persentase Prestasi Mahasiswa pada tes II

\begin{tabular}{ccccc}
\hline No. & $\begin{array}{c}\text { Angka } \\
\text { Mutu }\end{array}$ & $\begin{array}{c}\text { Huruf } \\
\text { Mutu }\end{array}$ & $\begin{array}{c}\text { Jumlah } \\
\text { Mahasiswa }\end{array}$ & $\begin{array}{c}\text { Persentase } \\
(\%)\end{array}$ \\
\hline 1. & $80-100$ & A & 15 & 45,45 \\
2. & $65-79$ & B & 13 & 39,40 \\
3. & $56-64$ & C & 5 & 15,15 \\
4. & $45-54$ & D & 0 & - \\
5. & $0-44$ & E & 0 & - \\
\hline & Jumlah & & $\mathbf{3 3}$ & $\mathbf{1 0 0}$ \\
\hline
\end{tabular}

Model pengajaran inkuiri yang berorientasi pada penemuan (discovery) ini memungkinkan mahasiswa untuk menemukan cara belajarnya masing-masing sehingga diharapkan mahasiswa tidak hanya tahu tetapi mereka memahami intisari materi tertentu. Dalam konteks pembelajaran tata bahasa, model inkuiri ini menempatkan mahasiswa sebagai subjek untuk mencapai tujuan pembelajaran yaitu dengan mencari dan memahami penggunaan rumusan/pola kalimat tertentu, sedangkan pengajar/dosen berperan sebagai fasilitator dan mediator untuk mengarahkan jalannya proses pembelajaran karena menciptakan, menjaga dan mengembangkan suasana belajar yang kondusif dan produktif merupakan kunci utama dari keberhasilan proses belajar.

Dari persepktif motivasional (seperti yang dikemukakan Johnson, dkk, 1981) dalam Slavin (2005:34) struktur tujuan kooperatifmenciptakan sebuah situasi di mana satu-satunya cara anggota kelompok bisa meraih tujuan pribadi mereka adalah jika kelompok mereka bisa sukses. Oleh kaena itu, untuk meraih tujuan personal mereka, anggota kelompok harus membantu teman satu timnya untuk melakukan apa pun guna membuat kelompok mereka berhasil, dan mungkin yang lebih penting, mendorong anggota satu kelompoknya untuk melakukan usaha maksimal.

Penerapan model inkuiri dalam pembelajaran tata bahasa yang dilakukan dalam penelitian inimenunjukkan adanya perubahan atau peningkatan pada penguasaan dan pemahaman mahasiswa dalam materi tata bahasa tertentu yaitu tema perbandingan (la comparaison) yang terdiri dari dua sub pokok bahasan yaitu le comparatif dan le superlatif seperti telah diuraikan di atas. Hasil penelitian ini menunjukkan penguasaan dan pemahaman para mahasiswa terhadap materi cukup merata.

Selain penguasaan dan pemahaman yang meningkat seperti terefleksikan pada hasil tes dari mahasiswa-mahasiswa ini, model ini juga memiliki hal yang bisa dikatakan kekurangan yaitu dari sisi waktu karena pelaksanaan model inkuiri berdasarkan penelitian yang dilakukan dalam dua siklus ini membutuhkan waktu yang relatiflebih lamadan juga dikarenakan jumlah mahasiswa yang cukup banyak.

\section{SIMPULAN}

Penelitian yang bertujuan untuk memecahkan permasalahan pada pengajaran tata bahasa pada mahasiswa semester 3 prodi pendidikan bahasa Prancis ini dilaksanakan dengan menerapkan model pengajaran berbasis inkuiri dengan menggunakan metode kaji tindak (action research) yang terdiri dari dua siklus.

Hasil penelitian ini menunjukkan bahwa model inkuiri yang merupakan model pembelajaran yang menekankan pada penemuan (discovery learning) dapat meningkatkan prestasi mahasiswa bahasa Prancis dalam menguasai dan memahami tata bahasa Prancis dan juga meninimalkan kesenjangan pada prestasi yang dihasilkan melalui kerja kelompok (kooperatif). Meskipun memiliki sedikit kekurangan yaitu antara lain lamanya waktu yang 
dibutuhkan serta lebih cocok untuk mahasiswa yang mempunyai kemampuan kognitif dan motivasi belajar yang lebih dari rata-rata, secara kesuruhan dapat disimpulkan bahwa model ini dapat meningkatkan prestasi mahasiswa dalam memahami tata bahasa Prancis, meningkatkan keaktifan dan kekreatifan mahasiswa dalam kelas dan memberikan kesempatan mahasiswa untuk mengembangkan mental intelektualnya dalam berpikir.

\section{DAFTAR RUJUKAN}

Anam, Khoirul. 2016. Pembelajaran Berbasis Inkuiri. Metode dan Aplikasi. Yogyakarta: Pustaka Pelajar

Dahlan. 1990. Model-model Mengajar (Beberapa Alternatif Interaksi Belajar Mengajar). Bandung: CV Diponegoro

Firdaus, Aziz. 2012. Metode Penelitian. Tangerang : Jelajah Nusa

Galisson, R et Coste, R. 1976. Dictionnaire de Didactiques des Langues. Paris : Librarie Hachette

Guidère, Mathieu. 2003. Méthodologie de la Recherche: Guide de jeune chercheur en lettres, science humaines et sociales (Maîtrise, DEA, Master, Docotorat). Paris : Ellipses Édition Marketing
Joyce, B et al . 2000. Models of Teaching. USA :APearson Education Company

Kurniasih, Imas - Sani, Berlin. 2015. Ragam Pengembangan Model Pembelajaran untuk Peningkatan Profesionalitas Guru. Jakarta: Kata Pena

Musa, Mohammad - Nurfitri, Titi. 1988. Metodologi Penelitian. Jakarta: Fajar Agung

Richards, Jack. 2002. Methodology in Language Teaching. An anthology of Current Practice. Cambridge: Cambridge University Press.

Setiyadi, Ag. Bambang. 2006. Metode Penelitian untuk Pengajaran Bahasa Asing. Pendekatan Kuantitatif dan Kualitatif. Yogyakarta: Graha Ilmu

Slavin, Robert E. 2005 . Cooperative Learning: Teori, Riset dan Praktik (Terjemahan). Bandung: Nusa Media

Sugiyono. 2006. Metode Penelitian. Pendekatan Kuantitatif, Kualitatif, dan $R \& D$. Bandung: Alfabeta

Tagliante, Christine. 1994. La Classe de Langue. Paris : CLE International

Vigner, Gérard. 2004. La Grammaire en FLE . Paris: Hachette 